\title{
FOR WHOM THE DISC TOLLS: INTERVERTEBRAL DISC DEGENERATION, BACK PAIN AND TOLL-LIKE RECEPTORS
}

\author{
D.G. Bisson ${ }^{1,2}$, M. Mannarino ${ }^{2}$, R. Racine ${ }^{2}$ and L. Haglund ${ }^{1,2, *}$ \\ ${ }^{1}$ Shriner's Hospital for Children, Montreal, Canada \\ ${ }^{2}$ Orthopaedic Research Laboratory, Department of Surgery, McGill University, Montreal, Canada
}

\begin{abstract}
Intervertebral disc (IVD) degeneration is characterised by catabolic and inflammatory processes that contribute largely to tissue degradation and chronic back pain. The disc cells are responsible for the pathological production of pro-inflammatory cytokines and catabolic enzymes leading to degeneration. However, this phenotypical change is poorly understood. Growing evidence in animal and human studies implicates Toll-like receptors (TLR) and their activation through danger-associated alarmins, found increasingly in degenerating IVDs. TLR signalling results in the release of pro-inflammatory cytokines and proteolytic enzymes that can directly cause IVD degeneration and back pain. This review aims to summarise the current literature on TLR activation in IVD degeneration and discuss potential treatment modalities to alleviate the inflammatory phenotype of disc cells in order to arrest IVD degeneration and back pain.
\end{abstract}

Keywords: Inflammation, proteases, catabolism, alarmins, pain, innervation.

*Address for correspondence: Dr Lisbet Haglund, PhD, Associate Professor, The Orthopaedic Research Laboratory, Montreal General Hospital, McGill University, 1650 Cedar Avenue, Room C10.148.2, Montreal, QC, H3G 1A4, Canada.

Telephone number: +514 9341934 Email: lisbet.haglund@mcgill.ca

Copyright policy: This article is distributed in accordance with Creative Commons Attribution Licence (http://creativecommons.org/licenses/by-sa/4.0/).

\begin{tabular}{|c|c|c|c|}
\hline \multirow{3}{*}{ ADAMTs } & List of Abbreviations & IL & interleukin \\
\hline & a disintegrin and metalloproteinase & IRAK1 & IL-1 receptor-associated kinase 1 \\
\hline & with thrombospondin motifs & IRF & IFN regulatory factor 3 \\
\hline $\mathrm{AF}$ & annulus fibrosus & IVD & intervertebral disc \\
\hline AP-1 & activator protein 1 & JNK & c-Jun N-terminal kinases \\
\hline BAX & $\begin{array}{l}\text { B-cell lymphoma 2-associated X } \\
\text { protein }\end{array}$ & $\begin{array}{l}\text { LPS } \\
\text { LRR }\end{array}$ & $\begin{array}{l}\text { lipopolysaccharide } \\
\text { leucine rich repeats }\end{array}$ \\
\hline BDNF & brain-derived neurotrophic factor & MAPK & mitogen-activated protein kinase \\
\hline $\mathrm{CCL}$ & chemokine ligand & MCP-1 & monocyte chemoattractant protein 1 \\
\hline CCR1 & C-C chemokine receptor 1 & MIP-2 & macrophage inflammatory protein 2 \\
\hline COX & cyclooxygenase & MMP & matrix metalloproteinase \\
\hline CXCL & $\mathrm{C}-\mathrm{X}-\mathrm{C}$ motif ligand 1 & $N F-\kappa B$ & nuclear factor kappa B \\
\hline DAMPs & danger-associated molecular & NGF & nerve growth factor \\
\hline & patterns & NP & nucleus pulposus \\
\hline ECM & extracellular matrix & PAMPs & pathogen-associated molecular \\
\hline G-CSF & granulocyte colony-stimulating & & patterns \\
\hline & factor & $\begin{array}{l}\text { PGE2 } \\
\text { PCES/PTCES? }\end{array}$ & prostaglandin E2 \\
\hline $\begin{array}{l}\text { HA } \\
\text { HMGB1 }\end{array}$ & hyaluronic acid & PGES/PTG & prostaglandin E synthase \\
\hline $\begin{array}{l}\text { HMGB1 } \\
\text { HSP }\end{array}$ & high-mobility group box 1 & PGN & peptidoglycan \\
\hline HSP & heat shock protein & PRR & pattern recognition receptor \\
\hline HTRA & high temperature requirement & RANTES & regulated on activation, normal $\mathrm{T}$ \\
\hline IFN & interferon & & cell expressed and secreted \\
\hline IKK & inhibitor of NF-kB kinase & RIG-I & retinoic-acid-inducible gene 1 \\
\hline
\end{tabular}




$\begin{array}{ll}\text { SLRPS } & \begin{array}{l}\text { small leucine-rich proteins } \\ \text { SMOC }\end{array} \\ \text { SOCS1 } & \begin{array}{l}\text { suppramolecular organising centre } \\ \text { secreted protein acidic and cysteine } \\ \text { rich }\end{array} \\ \text { SSL3 } & \begin{array}{l}\text { staphylococcal superantigen-like } \\ \text { protein 3 }\end{array} \\ \text { TGF } & \text { transforming growth factor } \\ \text { TIR } & \text { Toll/IL-receptor } \\ \text { TIRAP } & \text { TIR-domain-containing adapter } \\ \text { TLR } & \text { Toll-like receptor } \\ \text { TNF } & \text { tumour necrosis factor } \\ \text { TRAF6 } & \text { TNF receptor associated factor 6 } \\ \text { TRAM } & \text { TIR-domain-containing adapter- } \\ & \text { inducing IFN- } \beta \text {-related adapter } \\ \text { TRIF } & \text { molecule } \\ \text { VEGF } & \text { TNFR-associated factor } \\ & \text { vascular endothelial growth factor }\end{array}$

\section{Introduction}

\section{Disc degeneration}

Chronic back pain is a leading cause of disability and one of the largest burdens on health-related quality of life worldwide (Balagué et al., 2012; Vos et al., 2013). Studies have shown a strong correlation between chronic back pain and IVD degeneration (Hartvigsen et al., 2018). IVD degeneration is strongly associated with ageing and is characterised by structural and biochemical changes to the central gel-like NP and the surrounding lamellar AF. Loss in load-bearing function of the disc is due to a generalised catabolism of the ECM and negatively charged proteoglycans in the NP, with consequent decrease in water content and compressibility of the disc. Through increased catabolic enzyme activity, the AF becomes prone to micro-fissuring and tears that weaken its structural integrity and increase the risk of NP bulging and herniation (Lotz and Ulrich, 2006). The catabolic state is driven by disc cells producing inflammatory and degenerative factors that, in addition to breaking down the tissue, promote leukocyte infiltration (Rajasekaran et al., 2019; Risbud and Shapiro, 2013). However, the phenotypic shift in NP and AF cells remains poorly understood. The search for much-needed disease-modifying drugs to stop and potentially reverse disc degeneration could be reliant on the knowledge of these molecular mechanisms. The present review summarises the recent advances implicating TLRs, a class of cytoplasmic type I receptors, in the inflammatory phenotype of degenerating IVDs.

\section{TLRs}

Molecular pattern recognition is a crucial mechanism at the core of innate immunity and tissue repair. PRRs interact with a wide range of molecules from PAMPs to endogenous danger-associated molecules (alarmins or DAMPs) and induce an inflammatory response involved in tissue remodelling or host defence. RIG-1-like receptors, Nod-like receptors and most importantly the 10 mammalian members of the TLRs are the main actors that perform the PRR function in humans (Newton and Dixit, 2012). TLR1, 2 , 4, 5, 6 and 10 are located mainly on the cell surface while TLR3, 7, 8 and 9 reside in endosomal vesicles (Takeda and Akira, 2015). TLR activation is induced in 3 steps (Fitzgerald and Kagan, 2020; Kumar et al., 2013) (Fig. 1).

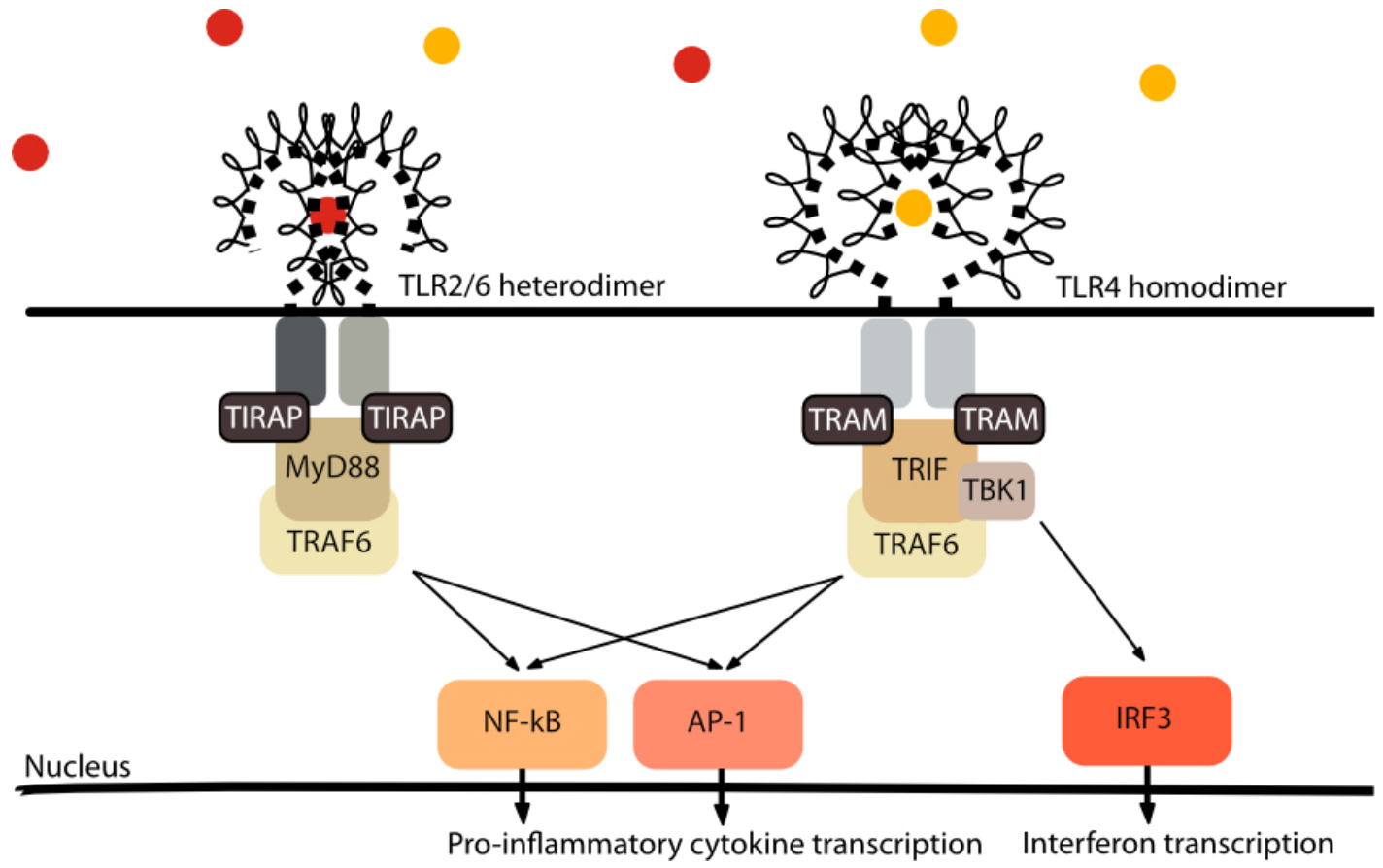

Fig. 1. Schematic representation of TLR activation by TLR2/4 agonist and TLR4 agonist and downstream signalling pathways. 
1. The agonist is trapped between the LRR-rich ectodomains of two TLR subunits. TLRs assemble in dimer pairs. In the present review, special attention is given to the TLR heterodimers TLR1/2 and TLR2/6 as well as the homodimer TLR4 due to their notable promiscuity in binding several alarmins and pathogens found in degenerating discs and their increased expression in degenerating IVD tissue. The proximity of two TLR subunits upon ligand binding induces the dimerisation their cytoplasmic TIR domain.

2. The intracellular dimerised TIR domains recruit membrane bound TIR-domain-containing TIRAP or TRAM, which proceed to organise a SMOC around one of two key proteins: MyD88 or TRIF. Most TLR dimers signal through MyD88dependent SMOC (myddosome). However, TLR4 homodimers can also activate the TRIFdependent SMOC (triffosome).

3. In both myddosome and triffosome activation, TRAF6 induces IKK and MAPK phosphorylation. Ultimately, the transcription factors NF- $\kappa \mathrm{B}$ and AP-1, which are translocated to the nucleus, are activated to induce transcription of proinflammatory genes. Recent research shows that the triffosome has the added ability to induce IFN1 signalling through IRF3.

These mechanisms are thought to induce an appropriate response according to the danger presented. For example, the bacterial cell wall component peptidoglycan, found mostly on grampositive bacteria, can activate TLR2/6 to release pro-inflammatory and chemotactic signals to recruit cells specialised in phagocytosis. Alternatively, viral nucleic acids can activate the TLR3/TLR4 TRIF-dependent pathway for a more suitable IFN-mediated antiviral response. Dimer-agonist specificity, co-effector stimulation and signalling pathway cross-talks with cytokines and other alarmins enable the flexibility of downstream inflammatory responses observed (Lin et al., 2017). These inflammatory pathways are highly dependent on multiple positive feedback loops to amplify the inflammatory signal for quick and efficient response to danger. However, downsides of this efficient and flexible inflammatory response are the vicious inflammatory cycle TLR activation often creates. The study hypothesis was that these feedback loops are driving the inflammatory processes involved in disc degeneration (Fig. 2). The following sections will summarise the evidence supporting the presence of these feedback loops and their involvement in IVD degeneration and chronic back pain.

\section{TLR activation in IVDs}

\section{Disc infections or PAMPs}

Disc infections caused by low-virulence anaerobic bacteria such as Cultibacterium acnes (C. acnes, formerly

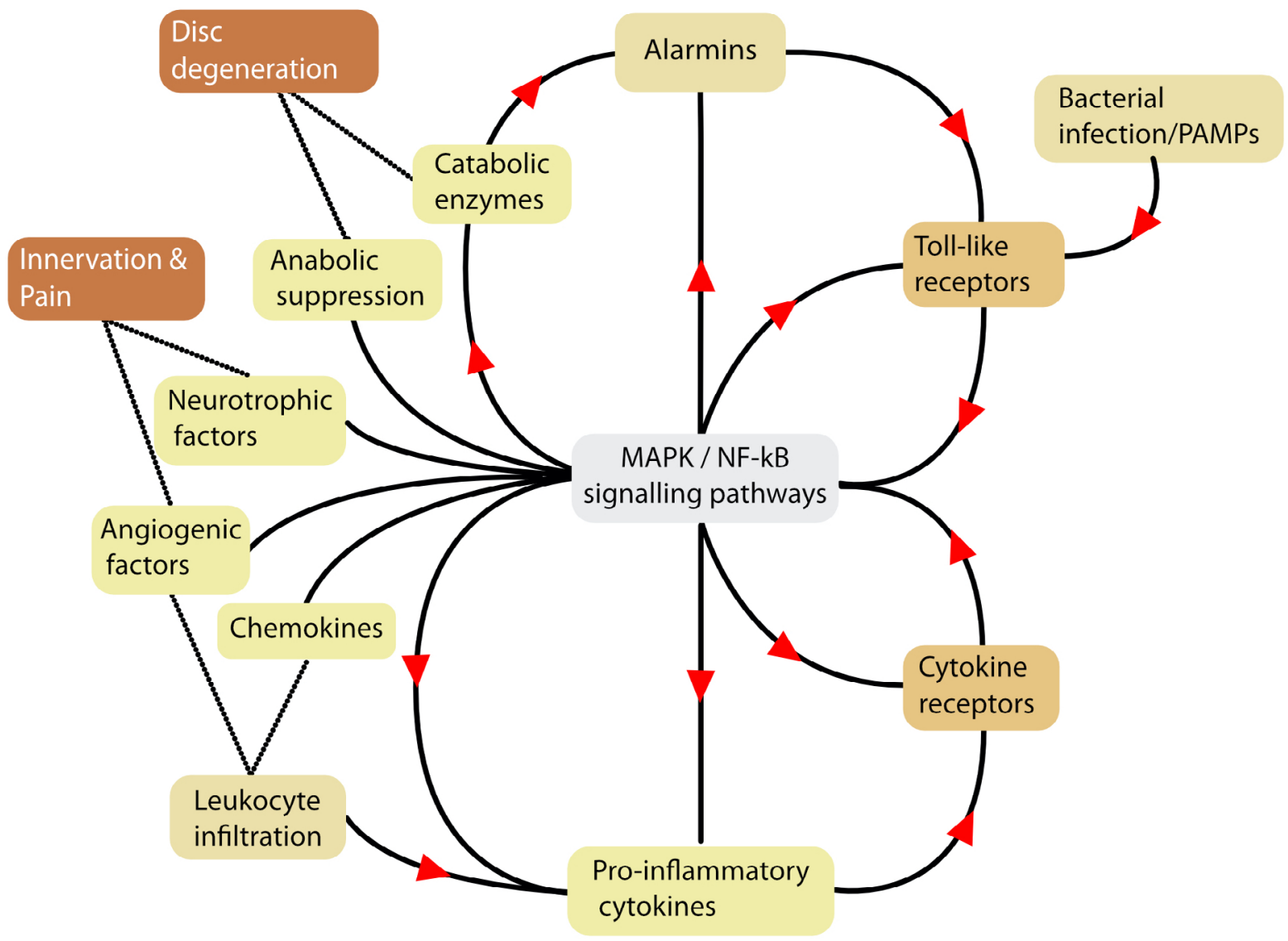

Fig. 2. TLR and cytokine receptor-centric positive feedback loops contributing to IVD degeneration and back pain. 
Propionobacterium acnes) have been hypothesised as contributors to disc degeneration and Modic changes in the adjacent vertebral bone. Stirling et al. (2001) reported that $53 \%$ of degenerative disc samples contain live bacteria. Since then, multiple groups have performed similar experiments finding varying levels of live $C$. acnes in degenerative disc tissues: 0 \% (Li et al., 2016), 4.2 \% (Neto et al., 2019), $10 \%$ (Schmid et al., 2020), $15.6 \%$ (Ahmed-Yahia et al., 2019), 21 \% (Yuan et al., 2017), 32 \% (Tang et al., 2018), 35 \% (Salehpour et al., 2019), 37 \% (Javanshir et al., 2017). This discrepancy can be explained by the propensity for contamination of clinical samples by C. acnes, one of the most abundant bacteria found on human skin (Mollerup et al., 2016). The best evidence for this phenomenon, although contested by Bråten et al. (2019), is the double-blind randomised clinical control trial for the efficacy of antibiotic treatment to alleviate chronic low-back pain and Modic type I changes (Albert et al., 2013). Regardless of the prevalence of bacterial infiltration in degenerating discs, in vitro human and in vivo animal investigations have revealed that $C$. acnes can survive in the disc environment and induce degeneration through the TLR pathway (Li et al., 2016; Lin et al., 2018). Human in vitro disc cell cultures respond to $C$. acnes contamination significantly increasing IL-6 mRNA production, which is decreased by Sparstolonin B (a TLR2/4 antagonist) treatment (Schmid et al., 2020). Interestingly, inoculation of rat caudal IVDs causes severe disc degeneration by triggering apoptosis of NP cells. Similar degeneration, with added Modic changes type I, is also found in inoculated rabbit IVDs (Chen et al., 2016). Furthermore, the time-dependent increase in Bax and cleaved caspase 3 following $C$. acnes infection is significantly reduced by knocking down TLR2 expression, indicating a central role for TLRs in bacterial infection of the IVD (Lin et al., 2018). Interestingly, new evidence suggests that the activation of the TLR2/MAPK pathway induces NP cells to phagocytise $S$. aureus. As an immune-deprived tissue, this mechanism might explain how discs attempt to control infection (Lin et al., 2019). Taken together, these studies suggest that the inflammatory response to infection produced by discs cells through TLRs can be detrimental to the disc tissue and enhance degeneration.

\footnotetext{
Alarmins

Sterile activation of TLRs in response to injury and stress is mediated through a class of ligands called DAMPs or alarmins. The term alarmin was introduced by Oppenheim in 2005 to classify endogenous molecules that have an immunostimulatory function once bioavailable (Oppenheim and Yang, 2005). For example, HMGB1 is a nuclear DNA-binding protein that can be actively secreted through non-canonical pathways by stressed and activated cells or passively released by leaky necrotic cells. Once released from the nucleus and the cell, the hydrophobic region of this protein can bind or interfere with multiple
}

membrane receptors including TLR2 and TLR4 (Janko et al., 2014). Interestingly, a significant increase in HMGB1 expression and immunopositivity was found in advanced disc degeneration, with up to 8-fold increase in Thomson grade 5 discs (Gruber et al., 2015; Shah et al., 2018). Other intracellular alarmins, such as peroxiredoxin-5, are also increased or uniquely present in degenerating discs compared to healthy young and aged discs (Rajasekaran et al., 2019). The second alarmin-producing mechanism is through proteolysis of the ECM. With increased matrixdegrading enzyme activity during degeneration, the collagen network loses integrity and releases otherwise sequestered matrix proteins. The SLRPs biglycan and decorin, for example, needs to be liberated from the matrix by proteases to become mobile and reach cell surface receptors (Roedig et al., 2019; Schaefer et al., 2005; Schaefer, 2014). Alarmins can also be generated by fragmenting core ECM components such as aggrecan, biglycan, fibronectin, fibromodulin and hyaluronan. In the case of aggrecan, the proteases MMP3, MMP13, ADAMTs-4 and ADAMTs-5 cleave the interglobular domain of the core protein to release a fragment named ACAN-32, a small peptide known to interact with TLR2 and cause inflammation (Lees et al., 2015; Miller et al., 2017). Additionally, various fragments of fibronectin have been shown to induce inflammatory responses such as a $30 \mathrm{kD}, 40 \mathrm{kD}, 45 \mathrm{kD}$ and $75 \mathrm{kD}$ fragment (Aota et al., 2005). Increased fragmentation of fibronectin and other ECM alarmins such as decorin, biglycan, fibromodulin and lumican are also found in degenerating IVDs (Brown et al., 2012; Melrose et al., 2001; Melrose et al., 2007; Singh et al., 2009). An exhaustive list of known alarmins is organised in Table 1.

\section{TLR activation amplifies inflammation}

\section{Pro-inflammatory cytokines}

The main outcome of TLR activation in any cell type is the production of pro-inflammatory cytokines (Takeda and Akira, 2015). The similarity in the intracellular domains of TLRs and IL-1 receptors explains the convergence of their pathways in ultimately activating the transcription factor NF- $\kappa B$ through MAPKs. Consequently, activation of most TLR dimers on disc cells will increase the production of pro-inflammatory cytokines. Studies in animal models and human samples have confirmed that IVD cells secrete IL-1 $\beta$, IL-3, IL-5, IL-6, IL-8, IL-7, IL-13, IL-15, IFN- $\gamma$ and TNF- $\alpha$ following TLR2 and/ or TLR4 activation (Fang and Jiang, 2016; Krock et al., 2017; Quero et al., 2013; Rajan et al., 2013; Schmid et al., 2020). These cytokines are directly linked to the progression of IVD degeneration and their importance is highlighted by their wide influence on cellular responses, including chemokine production, synergistic effects on TLR activation and catabolic enzyme secretion (Johnson et al., 2015). 
Table 1. Alarmins activating TLRs found in IVDs.

\begin{tabular}{|c|c|}
\hline TLR & Alarmin \\
\hline \multirow{5}{*}{ TLR2 } & Fibronectin fragments (Oegema et al., 2000) \\
& HA acid fragments (Quero et al., 2013) \\
& Biglycan (Melrose et al., 2007) \\
& HMG1 (Gruber et al., 2015; Shah et al., 2018) \\
& Versican (Sztrolovics et al., 2002) \\
& Histones (Rajasekaran et al., 2019) \\
& Fibromodulin (Melrose et al., 2007) \\
& Aggrecan fragment (Sztrolovics et al., 1997) \\
& Decorin (Zwambag et al., 2020) \\
\hline \multirow{5}{*}{ TLR4 } & Fibronectin fragments (Oegema et al., 2000) \\
& Thrombospondin-1 (Rajasekaran et al., 2019) \\
& Resistin (Li et al., 2017; Liu et al., 2016) \\
& Tenascin (Gruber et al., 2009) \\
& HSP60, HSP70 (Klawitter et al., 2014) \\
& Hyaluronic acid fragments (Quero et al., 2013) \\
& HMG1 (Gruber et al., 2015; Shah et al., 2018) \\
& Biglycan (Melrose et al., 2007) \\
& Lumican (Melrose et al., 2007) \\
& S100A8/A9 (Grad et al., 2016) \\
& Decorin (Zwambag et al., 2020) \\
\hline
\end{tabular}

\section{TLR pathway sensitisation}

One of the strongest amplification mechanisms for inflammatory signals is through the self-regulation of the TLR/cytokine pathways. First, TLR activation leads to an increased expression of TLRs, as demonstrated by many studies (Table 2). TLR4 activation using LPS stimulation results in increased TLR2 and TLR4 expression in disc cells (Ellman et al., 2012; Rajan et al., 2013). Also, TLR2 activation using Pam2CSK4 or peptidoglycan increases TLR2 expression in disc cells (Krock et al., 2017). Separately, cytokines can increase TLR expression. Disc cells activated by IL- $1 \beta$ result in a significant increase in TLR2 mRNA expression, whereas TNF- $\alpha$ significantly upregulates TLR1, 2 and 4 (Klawitter et al., 2014; Qin et al., 2016). Gawri et al. (2014) demonstrated that also injurious loading increases TLR2 and TLR4 expression in IVD cells. Studies on other tissue types have found similar relationships between mechanical loading and induction of TLR expression, such as stretching alveolar epithelial cells (Kuhn et al., 2014), cardiomyocytes (Shyu et al., 2010) and chondrocytes (Wang et al., 2011). Although the causality of TLR regulation through mechano-sensing is still being investigated, some studies have suggested that TLR upregulation is indirect and a consequence of alarmin production. Alarmins, such as PGE2 and HMGB1, are induced by mechanical stimulation and may, following TLR activation, induce their own expression (Wang et al., 2011; Wolfson et al., 2014). This causality still needs to be elucidated in the disc environment. However, to raise the sensitivity even more, some alarmins can be released directly from cells upon TLR activation, such as S100A8/A9 and HMGB1. Others are released indirectly after TLR activation through catabolic enzymes either liberating bound molecules, such as biglycan and decorin, from the matrix or by cleaving proteins into fragments, as in the case of aggrecan (32-mer), fibronectin, fibromodulin and hyaluronan (Dziki et al., 2018). Interestingly, Klawitter et al. (2014) reported a proportional increase in TLR1, TLR2, TLR4 and TLR6 expression in degenerating discs, which could be the consequence of repeated exposure to alarmins and pro-inflammatory cytokines.

\section{Leukocyte recruitment}

Chemotaxis to the IVD may be beneficial in the case of reparative stem cells homing to the disc, attracted, for example, through CCL5 production by degenerative disc cells (Pattapa et al., 2014). However, an excessive chemotactic signal can worsen disc degeneration by recruiting leukocytes. Macrophages, neutrophils and T-cells have been shown to infiltrate herniated and degenerate discs following the release of chemoattractant from disc cells (Grönblad et al., 1994; Risbud and Shapiro, 2013). The harsh environment of the degenerating IVD may promote leukocytes to further enhance the catabolic milieu through the activity of both cytokine receptors and TLRs. In fact, in vivo studies have shown the beneficial effect on disc degeneration from blocking macrophage recruitment through CCR1 (Chou et al., 2020). CCL5 or RANTES, a well-documented chemokine attracting macrophages, monocytes and T-cells, is over-expressed in degenerating Thomson grade VI-V discs, likely through TNF- $\alpha$ stimulation (Gruber et al., 2014). Interestingly, alarmin-induced TLR activation controls also chemokine release from disc cells. Decorin stimulates rat AF cells to significantly increase production of the chemokines MCP-1, RANTES and MIP-2. The upregulation is reduced by the TLR4 antagonist TAK-242. Similarly, the alarmin resistin, produced during disc degeneration, induces 
Table 2. Summary of differential gene and protein expression studies downstream of TLR activation in IVDs. HS: Homo sapiens; BT: Bos taurus; RN: Rattus norvegicus; OC: Oryctolagus cuniculus; Chondrodystrophic canine.

\begin{tabular}{|c|c|c|c|c|c|}
\hline Model & Organism & Agonist & $\begin{array}{c}\text { Gene expression } \\
\text { downstream }\end{array}$ & $\begin{array}{c}\text { Protein expression } \\
\text { downstream }\end{array}$ & Reference \\
\hline NP cells & HS & HA fragment & $\begin{array}{c}\text { Increase: } I L-1 \beta, \\
I L-6, I L-8, C O X-2, \\
M M P 1, M M P 13\end{array}$ & Increase: IL-6, MMP1 & $\begin{array}{l}\text { Quero et al., } \\
\quad 2013\end{array}$ \\
\hline $\begin{array}{l}\mathrm{NP} \text { and } \mathrm{AF} \\
\text { cells }\end{array}$ & HS & PGN, LPS & $\begin{array}{c}\text { Increase: } I L-1 \beta \text {, } \\
B D N F, N G F\end{array}$ & Increase: NGF & $\begin{array}{l}\text { Krock et al., } \\
\quad 2016\end{array}$ \\
\hline NP cells & HS & C. acnes & $\begin{array}{c}\text { Increase: IL-1 } \beta, \\
\text { IL-6, IL-8, COX-2, } \\
\text { iNOS, PTGES2 }\end{array}$ & Increase: IL-6, IL-8 & $\begin{array}{l}\text { Schmid et al., } \\
2020\end{array}$ \\
\hline AF cells & HS & HMGB1 & & $\begin{array}{c}\text { Increase: } \\
\text { prostaglandin E2, IL-6, } \\
\text { IL-8, TNF- } \alpha\end{array}$ & $\begin{array}{l}\text { Fang and } \\
\text { Jiang, } 2016\end{array}$ \\
\hline NP cells & HS & LPS & $\begin{array}{c}\text { Increase: MMP13, } \\
\text { ADAMTS-4, } \\
\text { ADAMTS-5, } \\
\text { TLR2, iNOS }\end{array}$ & & $\begin{array}{l}\text { Ellman et al., } \\
\quad 2012\end{array}$ \\
\hline Whole disc & HS & $\begin{array}{l}\text { Pam2CSK4, } \\
\text { Fibronectin- } \\
\text { fragment }\end{array}$ & $\begin{array}{c}\text { Increase: NGF, } \\
I L-1 \beta, T L R 2\end{array}$ & $\begin{array}{l}\text { Increase: MMP3, } \\
\text { MMP13, HTRA1, } \\
\text { Cathepsin D, IL-3, IL-5, } \\
\text { IL-6, IL-7, IL-10, IL-13, } \\
\text { IL-15, IFN- } \gamma, \text { TGF- } \beta \text {, } \\
\text { G-CSF, GRO, GM-CSF, } \\
\text { CXCL1, CCL8, CCL7 }\end{array}$ & $\begin{array}{l}\text { Krock et al., } \\
\quad 2017\end{array}$ \\
\hline Disc cells & $B T$ & LPS & $\begin{array}{c}\text { Increase: } I L-1 \beta, \\
I L-6, T N F-\alpha, T L R 4\end{array}$ & $\begin{array}{c}\text { Increase: TNF- } \alpha, \text { IL-1 } \beta \text {, } \\
\text { HMGB1 } \\
\text { Decrease: collagen } \\
\text { type II, aggrecan }\end{array}$ & $\begin{array}{l}\text { Rajan et al., } \\
2013\end{array}$ \\
\hline NP cells & $R N$ & LPS & $\begin{array}{c}\text { Increase: TLR4, } \\
T N F-\alpha, I L-1 \beta, I L-6\end{array}$ & $\begin{array}{c}\text { Increase: TNF- } \alpha, \text { IL-1 } \beta \text {, } \\
\text { HMGB1 }\end{array}$ & Qin et al., 2016 \\
\hline NP cells & HS & Resistin & Increase: CCL4 & Increase: CCL4 & Li et al., 2017 \\
\hline AF cells & $R N$ & Decorin & $\begin{array}{c}\text { Increase: } M I P-2, \\
\text { RANTES, } M C P-1, \\
\text { IL-6 }\end{array}$ & & $\begin{array}{l}\text { Zwambag } \\
\text { et al., } 2020\end{array}$ \\
\hline Whole disc & OC & $\begin{array}{l}\text { Fibronectin- } \\
\text { fragment }\end{array}$ & & $\begin{array}{l}\text { Decrease: aggrecan, } \\
\text { collagen type II }\end{array}$ & $\begin{array}{l}\text { Anderson } \\
\text { et al., } 2003\end{array}$ \\
\hline NP cells & $C C$ & LPS & $\begin{array}{c}\text { Increase: TNF- } \alpha, \\
I L-6, M M P 3, \\
M M P 13, V E G F, \\
P G E S\end{array}$ & & $\begin{array}{l}\text { Iwata et al., } \\
\quad 2013\end{array}$ \\
\hline
\end{tabular}

the release of CCL4 through TLR4 and NF- $\kappa$ B. The increase in CCL4 successfully attracts macrophages to the NP by binding to CCR1 (Li et al., 2017). In favour of leukocyte recruitment and infiltration, TLR activation results in neovascularisation through the production of angiogenic factors (Feng et al., 2018; Lee et al., 2011). An increase in potent factors, such as VEGF, was observed following TNF- $\alpha$ and LPS stimulation of the NF- $\kappa$ B pathway (Iwata et al., 2013; Ohba et al., 2009). Angiogenic factors attract new blood vessels to infiltrate AF fissures and encourage chemotaxis to the IVD (Haro et al., 2002). These results reveal another arm of the positive feedback loop potentially tying TLRs to disc degeneration through leukocyte recruitment. 
Table 3. Potential therapeutic agents for TLR pathway suppression in disc degeneration.

\begin{tabular}{|c|c|}
\hline TLR & Therapeutic agent \\
\hline TLR2 & $\begin{array}{c}\text { Candesartan (Barakat et al., 2014) } \\
\text { OPN-305 (Reilly et al., 2013) } \\
\text { M2000 (Aletaha et al., 2017) } \\
\text { Sparstolonin B (Liang et al., 2011) } \\
\text { CU-CPT22 (Cheng et al., 2012) } \\
\text { SSL3 (Koymans et al., 2018) } \\
\text { C29/o-Vanillin (Mistry et al., 2015) } \\
\text { Imidaziquinollines (Kužnik et al., 2011) }\end{array}$ \\
\hline TLR4 & $\begin{array}{l}\text { Resatorvid/TAK242 (Krock et al., 2018) } \\
\text { Candesartan (Barakat et al., 2014), } \\
\text { Valsartan (Yang et al., 2009) } \\
\text { Fluvastatin (Földes et al., 2008) } \\
\text { Simvastatin (Methe et al., 2005) } \\
\text { Naloxone/Naltrexone (Lewis et al., 2012) } \\
\text { Curcumin (Youn et al., 2006) } \\
\text { Dioscin (Qi et al., 2015) } \\
\text { Eritoran/E5564 (Kim et al., 2007) } \\
\text { NI-0101 (Monnet et al., 2017) } \\
\text { M2000 (Aletaha et al., 2017) } \\
\text { FP7 (Perrin-Cocon et al., 2017) } \\
\text { Sparstolonin B (Liang et al., 2011) } \\
\text { 6-shoagol (Park et al., 2009) } \\
\text { EGb761 (Chen et al., 2013) } \\
\text { PSMa1-a3 (Chu et al., 2018) } \\
\text { Oleocanthal (Iacono et al., 2010) } \\
\text { Lactoferricin (Kim et al., 2013) } \\
\text { Boswellic acid (Wang et al., 2014) } \\
\text { Procyanidin B3 (Shang et al., 2020) } \\
\text { TAP2 (Park et al., 2020) }\end{array}$ \\
\hline
\end{tabular}

\section{TLR activation promotes catabolism}

\section{Protease production}

Proteases involved in matrix degradation during IVD degeneration have been directly linked to NF$\kappa B$ activity (Wuertz et al., 2012). Furthermore, TLR activation results in the production of MMP1, MMP3 and MMP13 (which are the most upregulated MMPs in degenerating discs) in IVDs (Quero et al., 2013). MMPs have the ability to cleave a wide range of ECM molecules, such as fibronectin, aggrecan, decorin, tenascin and collagen type I and II, which are the main structural components of cartilaginous tissues. ADAMTs-4 and -5, two proteases highly prevalent in cartilaginous tissue degradation, are also under the control of TLR activation in disc cells (Ellman et al., 2012; Tian et al., 2013). Although, proteases are involved in physiological tissue remodelling, their continuous activation will lead to tissue deterioration and cell death.

\section{Anabolic suppression}

In addition to upregulation of matrix-degrading enzymes, TLR activation can also suppress matrix synthesis to further exacerbate catabolism. Both LPS and alarmin fibronectin-fragment have suppressive effects on proteoglycan expression in disc cells (Aota et al., 2006). Furthermore, TLR activation reduces the expression of other important structural proteins such as collagen type II and aggrecan, which are crucial for tissue organisation and function (Rajan et al., 2013). By promoting catabolic enzyme production and anabolic suppression, the TLR pathway seems to favour tissue catabolism once activated.

\section{TLR activation and pain}

TLR activation promotes innervation

Another pathology associated with TLR activation is discogenic and chronic back pain, in which the presence of neurites infiltrating the typically aneural IVDs are excited by factors released by degenerating IVDs (Freemont et al., 2002). Indeed, neurotrophic factors and NGF expression in human IVD cells are both regulated by TLR2 through NF- $\kappa B$ (Krock et al., 2016). Both NGF and BDNF promote neuron survival, maturation and growth. Additionally, in mature peripheral afferent fibres, NGF and BDNF can induce chronic neuronal sensitisation, resulting in the development of chronic pain (Pezet and McMahon, 2006). 


\section{TLR activation induces pain}

Silencing TLRs can reduce pain sensation caused by alarmins in in vivo models. Miller et al. (2015; 2017) found that alarmins, such as aggrecan 32-mer fragment and S100A8, stimulate TLR2 and TLR4, resulting in production of proalgesic chemokines in dorsal root ganglion nociceptive neurons and cause hyperalgesia when injected into a wild-type mouse knee. Furthermore, TLR-4-deficient mice, used as a model for neuropathic pain, are less sensitive to mechanical stimuli (Tanga et al., 2005). Moreover, back pain behaviour is relieved when measured in response to mechanical stimuli and cold allodynia in SPARC-null mice. The antagonist used in the study was TAK-242, a TLR4-specific antagonist (Krock et al., 2018). This was also seen in rats, where TAK-242 downregulates p65, IL-1 $\beta$ and TNF- $\alpha$ in the spinal cord dorsal horn, resulting in higher heat and mechanical pain thresholds (Zhao et al., 2015). These results support evidence linking disc-secreted cytokines generating painful stimuli in neighbouring neurons (Aoki et al., 2002). Studies on the effect of TLR activation upon discogenic pain are limited and need to be further explored for a more complete comprehension. For more information on the role of TLRs in persistent pain, a thorough review was published by Lacagnina et al. (2018).

To summarise, the multi-armed positive feedback loops centred around pro-inflammatory cytokines and TLRs are believed to play an important role in IVD degeneration. However, multiple in vitro and ex vivo experiments conducted in human, mouse, rat or bovine tissues show that these degenerative cascades can be triggered by TLR agonists as well as mechanical or inflammatory stimulation. Synthetic TLR agonists, alarmins or pathogen administration were all shown to induce disc degeneration (Krock et al., 2017; Rajan et al., 2013). This is supported by in vivo experiments on New Zealand white rabbits and rats where the injection of fibronectin-fragment, a known alarmin (Table 1), or LPS in the IVD causes a progressive inflammatory process similar to that seen in IVD degeneration (Anderson et al., 2003; Dudli et al., 2018). Therefore, it is imperative to find effective treatments to inhibit this vicious cycle and prevent disc degeneration.

\section{Therapeutic approaches}

Unfortunately, there is a lack of approved TLRspecific drugs to treat IVD degeneration. This section summarises different approaches that could be taken to reduce the degenerative environment induced by the TLR pathway in degenerating discs. The first approach is to neutralise molecules that will interfere with alarmin activity. The second is to suppress TLR expression in disc cells. The third is to modulate the downstream molecular cascade following TLR activation. For their similarity to disc cells, pathological changes and research interest, studies on TLR antagonists applied to chondrocytes or in osteoarthritis have been included. Further studies on TLR blocking agents in IVD cells are necessary to assess therapeutic efficiency and safety. A complete list of potential therapeutics can be found in Table 3 .

\section{Interfering with TLR agonists}

Antibodies binding specific alarmins have had some experimental success in reducing arthritis in mice, including blocking synovial HMGB1 with a polyclonal antibody (Kokkola et al., 2003). Pep-1, a HA-binding peptide, can prevent HA degradation into a lower molecular weight alarmin following IL-1 $\beta$ exposure and TLR activation (Campo et al., 2011). The disadvantage of blocking specific alarmins is the risk of limited efficacy compared to blocking the receptor. Blocking the ligands also inhibits their beneficial effects independent of TLRs.

\section{Blocking TLR activation}

Many antagonists have been found to inhibit either ligand binding or dimerisation of TLRs to block downstream activation. Regarding TLR binding inhibitors, some compounds have a TLR dimer specificity, such as TAK242 (TLR4 homodimer) and CU-CPT22 (TLR1/2 heterodimer) (Cheng et al., 2012; Takashima et al., 2009). TAK242 has shown potential to attenuate the release of catabolic factors such as IL-6, IL-8, MMP1, MMP3 and MMP13 in human chondrocytes (Seny et al., 2013). Exciting new research shows that systemic injection of TAK-242 in SPARCnull mice alleviates both IVD degeneration and back pain behaviour (Krock et al., 2018). In vitro studies have shown the benefit of blocking the TLR pathway in mouse discs using lactoferricin (TLR4 antagonist) after LPS or IL-1 $\beta$ insult (Kim et al., 2013). However, the translatability of TLR4 blocking in humans still needs evaluation. Other compounds, such as SSL3, have a wider blocking range on TLRs that seem to block TLR heterodimerisation (Koymans et al., 2015). Taking efficacy and risk/reward into account, the most effective TLR inhibitor for treating disc degeneration should target TLR2 and TLR4 specifically. A list of potential TLR2 and TLR4 inhibitors can be found in Table 3.

\section{Suppressing TLR expression}

As TLRs are overexpressed in degenerating IVDs, suppressing their expression in these tissues could be a viable therapeutic pathway to fend off aberrant activation. Some compounds such as curcumin, $o$-vanillin and triptolide have been found to decrease TLR2 and TLR4 mRNA expression after IL-1 $\beta$ prestimulation in human IVD cells (Klawitter et al., 2012). These effects were concurrent with lowered pro-inflammatory cytokine and protease expression, suggesting that the reduced TLR expression is a secondary effect to decreased inflammation. Another interesting option for suppressing TLR expression in diseased tissues is the use of gene-based therapies. MicroRNAs are important regulators of 
TLR expression. MiR-155 represses the negative regulator SOCS1 and MiR-146a downregulates TLR downstream components TRAF6 and IRAK1 (O'Neill et al., 2011). Similarly, Zhang et al. (2018) showed that overexpression of MiR-150-5p in disc cells inhibits increased TLR4 expression induced by LPS. This approach also reduces the LPS-mediated secretion of TNF- $\alpha$, IL- $1 \beta$ and IL- 6 , all while reversing the downregulation of aggrecan and collagen type II (Zhang et al., 2018). Therefore, interfering with microRNAs using expression vectors or antisense oligonucleotides might be an interesting therapy to block TLR pathways in IVDs. However, more studies are needed to solve delivery and off-target issues and improve safety and efficacy in vivo.

\section{Blocking downstream effectors of TLR activation}

The use of some compounds, such as vanillin, shown to interfere with MyD88 recruitment has resulted in recent advances in relieving pro-inflammatory and catabolic states of IVD cells (Mai et al., 2018; Mistry et al., 2015). The Chinese herb Sparstolonin B, interfering with MyD88 recruitment, downregulates TNF- $\alpha$, IL$1 \beta$ and IL- 6 expression in a mouse model of disc degeneration. Furthermore, Sparstolonin B decreases TLR4, MyD88 and NF- $\kappa$ B protein expression, suggesting that TLR pathway downregulation results in de-sensitisation (Ge et al., 2018). Studer et al. (2007) showed some efficacy in blocking MAPKs, such as JNK or p38, for suppressing inflammation. However, their usefulness is limited due to their ubiquity and having important functions in many other pathways. This probably explains why toxicity and side effects are commonly reported. A development of isoformspecific inhibitors may help in reducing side effects without affecting the response of targeted MAPK inhibition.

\section{Limitations}

There are two main limitations to this review. First, the evidence presented in the literature is still limited. Indeed, only two in vivo studies have described the inflammatory cascade inducing IVD degeneration through TLR activation. However, the abundance of research showing the consistent effects of TLR activation ex vivo and in vitro in other cell types solidify the IVD-specific literature covered in the present review. The second limitation is the lack of knowledge on the applicability of TLR-based therapeutics for IVD degeneration. As such, most of the therapeutic options listed in Table 3 were tested in other cell types. Although the TLR inhibition studies referenced have shown beneficial effects on disc homeostasis and inflammatory state, it is currently not known whether TLR inhibition has the potential to reverse IVD degeneration. Future studies are needed to confirm this hypothesis.

\section{Perspectives}

The question of the relative importance of the TLR pathway for tissue inflammation degradation and pain related to IVD degeneration remains largely unanswered. However, strong evidence is accumulating implicating TLRs in degenerating cartilaginous tissues, including IVDs. Further advances should aim to observe if the inflammatory and catabolic phenotype of disc cells can be reduced or reversed by TLR pathway interference in order to limit IVD degeneration and pain.

\section{Conclusion}

This review highlights the implication of TLR pathways in the phenotypic shift of NP and AF cells contributing to IVD degeneration and back pain. Although well controlled TLR activation may be important in tissue remodelling, uncontrolled activation of this pathway may lead to aberrant inflammation and tissue breakdown. Therefore, blocking TLRs may offer a potential diseasemodifying therapy for IVD degradation. This is important since there is currently an absence of disease-modifying drugs for IVD degeneration and back pain, which remains one of the most prevalent and debilitating diseases worldwide.

\section{Search method}

The search for literature was structured around different keywords, such as "Toll-like receptors", "infections", "alarmins" and "pain" in conjunction with the keyword "intervertebral disc" using the boolean operator AND. These keywords were searched in 3 main databases: Google Scholar, NCBI (PubMed) and the McGill Library catalogue.

\section{References}

Ahmed-Yahia S, Decousser J-W, FlouzatLachaniette CH, Dervin G, Roubineau F, Audureau E, Hourdille A, Royer G, Eymard F, Chevalier X (2019) Is the discopathy associated with Modic changes an infectious process? Results from a prospective monocenter study. Plos One 14: e0221030. DOI: 10.1371/journal.pone.0221030.

Albert HB, Sorensen JS, Christensen BS, Manniche C (2013) Antibiotic treatment in patients with chronic low back pain and vertebral bone edema (Modic type 1 changes): a double-blind randomized clinical controlled trial of efficacy. Eur Spine J 22: 697-707.

Aletaha S, Haddad L, Roozbehkia M, Bigdeli R, Asgary V, Mahmoudi M, Mirshafiey A (2017) M2000 $(\beta$-D-mannuronic acid) as a novel antagonist for 
blocking the TLR2 and TLR4 downstream signalling pathway. Scand J Immunol 85: 122-129.

Anderson DG, Li X, Tannoury T, Beck G, Balian G (2003) A fibronectin fragment stimulates intervertebral disc degeneration in vivo. Spine 28: 2338-2345.

Aoki Y, Rydevik B, Kikuchi S, Olmarker K (2002) Local application of disc-related cytokines on spinal nerve roots. Spine 27: 1614-1617.

Aota Y, An HS, Homandberg G, Thonar EJM-A, Andersson GBJ, Pichika R, Masuda K (2005) Differential effects of fibronectin fragment on proteoglycan metabolism by intervertebral disc cells \& colon; a comparison with articular chondrocytes. Spine 30: 722-728.

Aota Y, An HS, Imai Y, Thonar EJ, Muehleman C, Masuda K (2006) Comparison of cellular response in bovine intervertebral disc cells and articular chondrocytes: effects of lipopolysaccharide on proteoglycan metabolism. Cell Tissue Res 326: 787793.

Balagué F, Mannion AF, Pellisé F, Cedraschi C (2012) Non-specific low back pain. Lancet 379: 482491.

Barakat W, Safwet N, El-Maraghy NN, Zakaria MNM (2014) Candesartan and glycyrrhizin ameliorate ischemic brain damage through downregulation of the TLR signaling cascade. Eur J Pharmacol 724: 43-50.

Bråten LCH, Rolfsen MP, Espeland A, Wigemyr M, Aßmus J, Froholdt A, Haugen AJ, Marchand GH, Kristoffersen PM, Lutro O, Randen S, Wilhelmsen M, Winsvold BS, Kadar TI, Holmgard TE, Vigeland MD, Vetti N, Nygaard ØP, Lie BA, Hellum C, Anke A, Grotle M, Schistad EI, Skouen JS, Grøvle L, Brox JI, Zwart J-A, Storheim K, group A study (2019) Efficacy of antibiotic treatment in patients with chronic low back pain and Modic changes (the AIM study): double blind, randomised, placebo controlled, multicentre trial. BMJ 367: 15654. DOI: 10.1136/bmj. 15654.

Brown S, Melrose J, Caterson B, Roughley P, Eisenstein SM, Roberts S (2012) A comparative evaluation of the small leucine-rich proteoglycans of pathological human intervertebral discs. Eur Spine J 21: 154-159.

Campo GM, Avenoso A, Nastasi G, Micali A, Prestipino V, Vaccaro M, D'Ascola A, Calatroni A, Campo S (2011) Hyaluronan reduces inflammation in experimental arthritis by modulating TLR-2 and TLR-4 cartilage expression. Biochim Biophys Acta 1812: 1170-1181.

Chen YJ, Tsai KS, Chiu CY, Yang TH, Lin TH, Fu WM, Chen CF, Yang RS, Liu SH (2013) EGb761 inhibits inflammatory responses in human chondrocytes and shows chondroprotection in osteoarthritic rat knee. J Orthop Res 31: 1032-1038.

Chen Z, Zheng Y, Yuan Y, Jiao Y, Xiao J, Zhou Z, Cao P (2016) Modic Changes and disc degeneration caused by inoculation of propionibacterium acnes inside intervertebral discs of rabbits: a pilot study. Biomed Res Int 2016: 1-7.
Cheng K, Wang X, Zhang S, Yin H (2012) Discovery of small-molecule inhibitors of the TLR1/ TLR2 complex. Angew Chem Int Ed Engl 124: 1241212415.

Chou P-H, Chee A, Shi P, Lin C-L, Zhao Y, Zhang L, An HS (2020) Small molecule antagonist of C-C chemokine receptor 1 (CCR1) reduces disc inflammation in the rabbit model. Spine J 20: 20252036.

Chu M, Zhou M, Jiang C, Chen X, Guo L, Zhang M, Chu Z, Wang Y (2018) Staphylococcus aureus phenolsoluble Modulins $\alpha 1-\alpha 3$ act as novel toll-like receptor (TLR) 4 antagonists to inhibit HMGB1/TLR4/NF- $\kappa B$ signaling pathway. Front Immunol 9: 862. DOI: 10.3389/fimmu.2018.00862.

Dziki JL, Hussey G, Badylak SF (2018) Alarmins of the extracellular space. Semin Immunol 38: 33-39.

Dudli S, Liebenberg E, Magnitsky S, Lu B, Lauricella M, Lotz JC (2018) Modic type 1 change is an autoimmune response that requires a proinflammatory milieu provided by the 'Modic disc.' Spine J 18: 831-844.

Ellman MB, Kim J-S, An HS, Chen D, KC R, An J, Dittakavi T, Wijnen AJ van, Cs-Szabo G, Li X, Xiao G, An S, Kim S-G, Im H-J (2012) Toll-like receptor adaptor signaling molecule MyD88 on intervertebral disk homeostasis: in vitro, ex vivo studies. Gene 505: 283-290.

Fang F, Jiang D (2016) IL-1 $/$ HMGB1 signalling promotes the inflammatory cytokines release via TLR signalling in human intervertebral disc cells. Bioscience Rep 36: e00379. DOI: 10.1042/BSR20160118.

Feng Y, Ke J, Cao P, Deng M, Li J, Cai H, Meng Q, Li Y, Long X (2018) HMGB1-induced angiogenesis in perforated disc cells of human temporomandibular joint. J Cell Mol Med 22: 1283-1291.

Fitzgerald KA, Kagan JC (2020) Toll-like receptors and the control of immunity. Cell 180: 1044-1066.

Földes G, Haehling S von, Okonko DO, Jankowska EA, Poole-Wilson PA, Anker SD (2008) Fluvastatin reduces increased blood monocyte Toll-like receptor 4 expression in whole blood from patients with chronic heart failure. Int J Cardiol 124: 80-85.

Freemont AJ, Watkins A, Maitre CL, Baird P, Jeziorska M, Knight MTN, Ross ERS, O’Brien JP, Hoyland JA (2002) Nerve growth factor expression and innervation of the painful intervertebral disc. J Pathology 197: 286-292.

Gawri R, Rosenzweig DH, Krock E, Ouellet JA, Stone LS, Quinn TM, Haglund L (2014) High mechanical strain of primary intervertebral disc cells promotes secretion of inflammatory factors associated with disc degeneration and pain. Arthritis Res Ther 16: R21. DOI: 10.1186/ar4449.

Ge J, Chen L, Yang Y, Lu X, Xiang Z (2018) Sparstolonin B prevents lumbar intervertebral disc degeneration through Toll like receptor 4, NADPH oxidase activation and the protein kinase B signaling pathway. Mol Med Rep 17: 1347-1353.

Grad S, Zhang Y, Rozhnova O, Schelkunova E, Mikhailovsky M, Sadovoy M, Haglund L, Ouellet J, 
Alini M (2016) Differential gene expression profiles of cells from normal, traumatic and idiopathic scoliotic discs identify molecular dysregulation in scoliosis. Global Spine J 6: s-0036-1582635-s-0036-1582635. DOI: 10.1055/s-0036-1582635.

Grönblad M, Virri J, Tolonen J, Seitsalo S, Kääpä E, Kankare J, Myllynen P, Karaharju EO (1994) A controlled immunohistochemical study of inflammatory cells in disc herniation tissue. Spine 19: 2744-2751.

Gruber H, Ingram J, Jr EH (2009) Tenascin in the human intervertebral disc: alterations with aging and disc degeneration. Biotech Histochem 77: 37-41.

Gruber HE, Hoelscher GL, Bethea S, Ingram J, Cox M, Hanley EN (2015) High-mobility group box-1 gene, a potent proinflammatory mediators, is upregulated in more degenerated human discs in vivo and its receptor upregulated by TNF- $\alpha$ exposure in vitro. Exp Mol Pathol 98: 427-30.

Gruber HE, Hoelscher GL, Ingram JA, Bethea S, Norton HJ, Hanley EN (2014) Production and expression of RANTES (CCL5) by human disc cells and modulation by IL-1- $\beta$ and TNF- $\alpha$ in 3D culture. Exp Mol Pathol 96: 133-138.

Haro H, Kato T, Komori H, Osada M, Shinomiya K (2002) Vascular endothelial growth factor (VEGF)induced angiogenesis in herniated disc resorption. J Orthopaed Res 20: 409-415.

Hartvigsen J, Hancock MJ, Kongsted A, Louw Q, Ferreira ML, Genevay S, Hoy D, Karppinen J, Pransky G, Sieper J, Smeets RJ, Underwood M, Group LLBPSW, Buchbinder R, Hartvigsen J, Cherkin D, Foster NE, Maher CG, Underwood M, Tulder M van, Anema JR, Chou R, Cohen SP, Costa LM, Croft P, Ferreira M, Ferreira PH, Fritz JM, Genevay S, Gross DP, Hancock MJ, Hoy D, Karppinen J, Koes BW, Kongsted A, Louw Q, Öberg B, Peul WC, Pransky G, Schoene M, Sieper J, Smeets RJ, Turner JA, Woolf A (2018) What low back pain is and why we need to pay attention. Lancet 391: 2356-2367.

Iacono A, Gómez R, Sperry J, Conde J, Bianco G, Meli R, Gómez-Reino JJ, Smith AB, Gualillo O (2010) Effect of oleocanthal and its derivatives on inflammatory response induced by lipopolysaccharide in a murine chondrocyte cell line. Arthritis Rheum 62: 1675-1682.

Iwata M, Ochi H, Asou Y, Haro H, Aikawa T, Harada Y, Nezu Y, Yogo T, Tagawa M, Hara Y (2013) Variations in gene and protein expression in canine chondrodystrophic nucleus pulposus cells following long-term three-dimensional culture. Plos One 8: e63120. DOI: 10.1371/journal.pone.0063120.

Janko C, Filipović M, Munoz LE, Schorn C, Schett G, Ivanović-Burmazović I, Herrmann M (2014) Redox modulation of HMGB1-related signaling. Antioxid Redox Signal 20: 1075-1085. DOI: 10.1089/ ars.2013.5179.

Javanshir N, Salehpour F, Aghazadeh J, Mirzaei F, Alavi SAN (2017) The distribution of infection with Propionibacterium acnes is equal in patients with cervical and lumbar disc herniation. Eur Spine J 26: 3135-3140.
Johnson Z, Schoepflin Z, Choi H, Shapiro I, Risbud M (2015) Disc in flames: roles of TNF- $\alpha$ and IL-1 $\beta$ in intervertebral disc degeneration. Eur Cell Mater 30: 104-117.

Kim HM, Park BS, Kim J-I, Kim SE, Lee J, Oh SC, Enkhbayar P, Matsushima N, Lee H, Yoo OJ, Lee J-O (2007) Crystal structure of the TLR4-MD-2 complex with bound endotoxin antagonist Eritoran. Cell 130: 906-917.

Kim J-S, Ellman MB, Yan D, An HS, Kc R, Li X, Chen D, Xiao G, Cs-Szabo G, Hoskin DW, Buechter DD, Wijnen AJV, Im H-J (2013) Lactoferricin mediates anti-inflammatory and anti-catabolic effects via inhibition of IL-1 and LPS activity in the intervertebral disc. J Cell Physiol 228: 1884-1896.

Klawitter M, Quero L, Klasen J, Liebscher T, Nerlich A, Boos N, Wuertz K (2012) Triptolide exhibits anti-inflammatory, anti-catabolic as well as anabolic effects and suppresses TLR expression and MAPK activity in IL-1 $\beta$ treated human intervertebral disc cells. Eur Spine J 21: 850-859.

Klawitter M, Hakozaki M, Kobayashi H, Krupkova O, Quero L, Ospelt C, Gay S, Hausmann O, Liebscher T, Meier U, Sekiguchi M, Konno S, Boos N, Ferguson SJ, Wuertz K (2014) Expression and regulation of Toll-like receptors (TLRs) in human intervertebral disc cells. Eur Spine J 23: 1878-1891.

Klawitter M, Quero L, Klasen J, Gloess AN, Klopprogge B, Hausmann O, Boos N, Wuertz K (2012b) Curcuma DMSO extracts and curcumin exhibit an anti-inflammatory and anti-catabolic effect on human intervertebral disc cells, possibly by influencing TLR2 expression and JNK activity. J Inflamm 9: 29. DOI: 10.1186/1476-9255-9-29.

Kokkola R, Li J, Sundberg E, Aveberger A-C, Palmblad K, Yang H, Tracey KJ, Andersson U, Harris HE (2003) Successful treatment of collagen-induced arthritis in mice and rats by targeting extracellular high mobility group box chromosomal protein 1 activity. Arthritis Rheum 48: 2052-2058.

Koymans KJ, Feitsma LJ, Bisschop A, Huizinga EG, Strijp JAG van, Haas CJC de, McCarthy AJ (2018) Molecular basis determining species specificity for TLR2 inhibition by staphylococcal superantigen-like protein 3 (SSL3). Vet Res 49: 115. DOI: 10.1186/s13567018-0609-8.

Koymans KJ, Feitsma LJ, Brondijk THC, Aerts PC, Lukkien E, Lössl P, Kessel KPM van, Haas CJC de, Strijp JAG van, Huizinga EG (2015) Structural basis for inhibition of TLR2 by staphylococcal superantigen-like protein 3 (SSL3). Proc Natl Acad Sci U S A 112: 11018-11023.

Krock E, Currie JB, Weber MH, Ouellet JA, Stone LS, Rosenzweig DH, Haglund L (2016a) Nerve growth factor is regulated by Toll-like receptor 2 in human intervertebral discs. J Biol Chem 291: 35413551.

Krock E, Currie JB, Weber MH, Ouellet J, Stone LS, Rosenzweig DH, Haglund L (2016b) Toll-like receptor 2 regulates nerve growth factor synthesis via NF- $\kappa$ B signaling in human intervertebral disc cells. 
Global Spine J 6: s-0036-1582634-s-0036-1582634. DOI: 10.1055/s-0036-1582634.

Krock E, Millecamps M, Currie JB, Stone LS, Haglund L (2018) Low back pain and disc degeneration are decreased following chronic toll-like receptor 4 inhibition in a mouse model. Osteoarthritis Cartilage 26: 1236-1246.

Krock E, Rosenzweig DH, Currie JB, Bisson DG, Ouellet JA, Haglund L (2017) Toll-like receptor activation induces degeneration of human intervertebral discs. Sci Rep 7: 17184. DOI: 10.1038/ s41598-017-17472-1.

Kuhn H, Petzold K, Hammerschmidt S, Wirtz H (2014) Interaction of cyclic mechanical stretch and Toll-like receptor 4-mediated innate immunity in rat alveolar type II cells. Respirology 19: 67-73.

Kumar H, Takeuchi O, Akira S (2013) Encyclopedia of Biological Chemistry (2nd Edition). Signaling. Editors: Lennarz W, Lane M. Academic Press pp: 396-401.

Kužnik A, Benčina M, Švajger U, Jeras M, Rozman B, Jerala R (2011) Mechanism of endosomal TLR inhibition by antimalarial drugs and Imidazoquinolines. J Immunol 186: 4794-4804.

Lacagnina MJ, Watkins LR, Grace PM (2018) Toll-like receptors and their role in persistent pain. Pharmacol Therapeut 184: 145-158.

Lee JM, Song JY, Baek M, Jung H, Kang H, Han IB, Kwon YD, Shin DE (2011) Interleukin-1 $\beta$ induces angiogenesis and innervation in human intervertebral disc degeneration. J Orthop Res 29: 265-269.

Lees S, Golub SB, Last K, Zeng W, Jackson DC, Sutton P, Fosang AJ (2015) Bioactivity in an aggrecan 32-mer fragment is mediated via Toll-like receptor 2. Arthritis Rheumatol 67: 1240-1249.

Lewis SS, Loram LC, Hutchinson MR, Li C-M, Zhang Y, Maier SF, Huang Y, Rice KC, Watkins LR (2012) (+)-Naloxone, an opioid-inactive Toll-like receptor 4 signaling inhibitor, reverses multiple models of chronic neuropathic pain in rats. J Pain 13: 498-506.

Li B, Dong Z, Wu Y, Zeng J, Zheng Q, Xiao B, Cai X, Xiao Z (2016) Association between lumbar disc degeneration and propionibacterium acnes infection. Spine 41: E764-E769.

Li Z, Wang X, Pan H, Yang H, Li X, Zhang K, Wang H, Zheng Z, Liu H, Wang J (2017) Resistin promotes CCL4 expression through Toll-like receptor-4 and activation of the p38-MAPK and NF- $\kappa B$ signaling pathways: implications for intervertebral disc degeneration. Osteoarthritis Cartilage 25: 341-350.

Liang Q, Wu Q, Jiang J, Duan J, Wang C, Smith MD, Lu H, Wang Q, Nagarkatti P, Fan D (2011) Characterization of Sparstolonin B, a Chinese herbderived compound, as a selective Toll-like receptor antagonist with potent anti-inflammatory properties. J Biol Chem 286: 26470-26479.

Lin B, Dutta B, Fraser IDC (2017) Systematic investigation of multi-TLR sensing identifies regulators of sustained gene activation in macrophages. Cell Syst 5: 25-37.e3. DOI: 10.1016/j. cels.2017.06.014.

Lin Y, Cong H, Liu K, Jiao Y, Yuan Y, Tang G, Chen Y, Zheng Y, Xiao J, Li C, Chen Z, Cao P (2019) Microbicidal phagocytosis of nucleus pulposus cells against Staphylococcus aureus via the TLR2/MAPKs signaling pathway. Front Immunol 10: 1132. DOI: 10.3389/fimmu.2019.01132.

Lin Y, Jiao Y, Yuan Y, Zhou Z, Zheng Y, Xiao J, Li C, Chen Z, Cao P (2018) Propionibacterium acnes induces intervertebral disc degeneration by promoting nucleus pulposus cell apoptosis via the TLR2/JNK/ mitochondrial-mediated pathway. Emerg Microbes Infec 7: 1. DOI: 10.1038/s41426-017-0002-0.

Liu C, Yang H, Gao F, Li X, An Y, Wang J, Jin A (2016) Resistin promotes intervertebral disc degeneration by upregulation of ADAMTS- 5 through p38 MAPK signaling pathway. Spine 41: 1414-1420.

Lotz JC, Ulrich JA (2006) Innervation, inflammation, and hypermobility may characterize pathologic disc degeneration: review of animal model data. J Bone Jt Surg Am 88 Suppl 2: 76-82.

Mai C-W, Kang YB, Hamzah AS, Pichika MR (2018) Comparative efficacy of vanilloids in inhibiting Toll-like receptor-4 (TLR-4)/myeloid differentiation factor (MD-2) homodimerisation. Food Funct 9: 33443350.

Melrose J, Ghosh P, Taylor TKF (2001) A comparative analysis of the differential spatial and temporal distributions of the large (aggrecan, versican) and small (decorin, biglycan, fibromodulin) proteoglycans of the intervertebral disc. J Anat 198: 3-15.

Melrose J, Smith SM, Fuller ES, Young AA, Roughley PJ, Dart A, Little CB (2007) Biglycan and fibromodulin fragmentation correlates with temporal and spatial annular remodelling in experimentally injured ovine intervertebral discs. Eur Spine J 16: 2193-2205.

Methe H, Kim J-O, Kofler S, Nabauer M, Weis M (2005) Statins decrease Toll-like receptor 4 expression and downstream signaling in human CD14+ monocytes. Arterioscler Thromb Vasc Biol 25: 14391445.

Miller RE, Belmadani A, Ishihara S, Tran PB, Ren D, Miller RJ, Malfait A-M (2015) Damage-associated molecular patterns generated in osteoarthritis directly excite murine nociceptive neurons through Toll-like receptor 4. Arthritis Rheumatol 67: 2933-2943.

Miller RE, Miller RJ, Ishihara S, Tran PB, Golub SB, Last K, Fosang AJ, Malfait A-M (2017) An aggrecan fragment drives osteoarthritis pain through Tolllike receptor 2. BioRxiv: 160432. DOI: 10.1172/jci. insight.95704.

Mistry P, Laird MHW, Schwarz RS, Greene S, Dyson T, Snyder GA, Xiao TS, Chauhan J, Fletcher S, Toshchakov VY, MacKerell AD, Vogel SN (2015) Inhibition of TLR2 signaling by small molecule inhibitors targeting a pocket within the TLR2 TIR domain. P Natl Acad Sci U S A 112: 5455-5460. 
Mollerup S, Friis-Nielsen J, Vinner L, Hansen TA, Richter SR, Fridholm H, Herrera JAR, Lund O, Brunak S, Izarzugaza JMG, Mourier T, Nielsen LP, Hansen AJ (2016) Propionibacterium acnes: diseasecausing agent or common contaminant? Detection in diverse patient samples by next-generation sequencing. J Clin Microbiol 54: 980-987.

Monnet E, Lapeyre G, Poelgeest E van, Jacqmin P, Graaf K de, Reijers J, Moerland M, Burggraaf J, Min C de (2017) Evidence of NI-0101 pharmacological activity, an anti-TLR4 antibody, in a randomized phase I dose escalation study in healthy volunteers receiving LPS. Clin Pharmacol Ther 101: 200-208.

Neto NA, Wajchenberg M, Kanas M, Gotfryd AO, Lenza M, Martins DE (2019) Subclinical Propionibacterium acnes infection estimation in the intervertebral disc (SPInE-ID): protocol for a prospective cohort. BMJ Open 7: e017930. DOI: 10.1136/bmjopen-2017-017930.

Newton K, Dixit VM (2012) Signaling in innate immunity and inflammation. Csh Perspect Biol 4: a006049. DOI: 10.1101/cshperspect.a006049.

Oegema TR, Johnson SL, Aguiar DJ, Ogilvie JW (2000) Fibronectin and its fragments increase with degeneration in the human intervertebral disc. Spine 25: 2742-2747.

Ohba T, Haro H, Ando T, Wako M, Suenaga F, Aso Y, Koyama K, Hamada Y, Nakao A (2009) TNF- $\alpha$-induced NF- $\kappa$ B signaling reverses age-related declines in VEGF induction and angiogenic activity in intervertebral disc tissues. J Orthop Res 27: 229-235.

O’Neill LA, Sheedy FJ, McCoy CE (2011) MicroRNAs: the fine-tuners of Toll-like receptor signalling. Nat Rev Immunol 11: 163-175.

Oppenheim JJ, Yang D (2005) Alarmins: chemotactic activators of immune responses. Curr Opin Immunol 17: 359-365.

Pattappa G, Peroglio M, Sakai D, Mochida J, Benneker L, Alini M, Grad S (2014) CCL5/RANTES is a key chemoattractant released by degenerative intervertebral discs in organ culture. Eur Cell Mater 27: 124-136.

Park H, Hong J, Yin Y, Joo Y, Kim Y, Shin J, Kwon HH, Shin N, Shin HJ, Beom J, Kim DW, Kim J (2020) TAP2, a peptide antagonist of Toll-like receptor 4 , attenuates pain and cartilage degradation in a monoiodoacetate-induced arthritis rat model. Sci Rep 10: 17451. DOI: 10.1038/s41598-020-74544-5.

Park S-J, Lee M-Y, Son B-S, Youn H-S (2009) TBK1targeted suppression of TRIF-dependent signaling pathway of Toll-like receptors by 6-Shogaol, an active component of ginger. Biosci Biotechnology Biochem 73: 1474-1478.

Perrin-Cocon L, Aublin-Gex A, Sestito SE, Shirey KA, Patel MC, André P, Blanco JC, Vogel SN, Peri F, Lotteau V (2017) TLR4 antagonist FP7 inhibits LPS-induced cytokine production and glycolytic reprogramming in dendritic cells, and protects mice from lethal influenza infection. Sci Rep 7: 40791. DOI: 10.1038/srep40791.
Pezet S, McMahon SB (2006) Neurotrophins: mediators and modulators of pain. Annu Rev Neurosci 29: 507-538.

Qi M, Zheng L, Qi Y, Han X, Xu Y, Xu L, Yin L, Wang C, Zhao Y, Sun H, Liu K, Peng J (2015) Dioscin attenuates renal ischemia/reperfusion injury by inhibiting the TLR4/MyD88 signaling pathway via up-regulation of HSP70. Pharmacol Res 100: 341-352.

Qin C, Zhang B, Zhang L, Zhang Z, Wang L, Tang L, Li S, Yang Y, Yang F, Zhang P, Yang B (2016) MyD88-dependent Toll-like receptor 4 signal pathway in intervertebral disc degeneration. Exp Ther Med 12: 611-618.

Quero L, Klawitter M, Schmaus A, Rothley M, Sleeman J, Tiaden AN, Klasen J, Boos N, Hottiger MO, Wuertz K, Richards PJ (2013) Hyaluronic acid fragments enhance the inflammatory and catabolic response in human intervertebral disc cells through modulation of Toll-like receptor 2 signalling pathways. Arthritis Res Ther 15: R94. DOI: 10.1186/ ar4274.

Rajan NE, Bloom O, Maidhof R, Stetson N, Sherry B, Levine M, Chahine NO (2013) Toll-like receptor 4 (TLR4) expression and stimulation in a model of intervertebral disc inflammation and degeneration. Spine 38: 1343-1351.

Rajasekaran S, Tangavel C, Anand SV, Raja DC, Nayagam SM, Matchado MS, Raveendran M, Shetty AP, Kanna RM, Dharmalingam K (2019) Inflammaging determines health and disease in lumbar discs - evidence from differing proteomic signatures of healthy, ageing and degenerating discs. Spine J 20: 48-59.

Reilly M, Miller RM, Thomson MH, Patris V, Ryle P, McLoughlin L, Mutch P, Gilboy P, Miller C, Broekema M, Keogh B, McCormack W, Rooij JW de (2013) Randomized, double-blind, placebocontrolled, dose-escalating phase I, healthy subjects study of intravenous OPN-305, a humanized antiTLR2 antibody. Clin Pharmacol Ther 94: 593-600.

Risbud MV, Shapiro IM (2013) Role of cytokines in intervertebral disc degeneration: pain and disc content. Nat Rev Rheumatology 10: 44-56.

Roedig H, Nastase MV, Wygrecka M, Schaefer L (2019) Breaking down chronic inflammatory diseases: the role of biglycan in promoting a switch between inflammation and autophagy. FEBS J 286: 2965-2979.

Salehpour F, Aghazadeh J, Mirzaei F, Ziaeii E, Alavi SAN (2019) Propionibacterium acnes infection in disc material and different antibiotic susceptibility in patients with lumbar disc herniation. Int J Spine Surg 13: 146-152.

Schaefer L (2014) Complexity of danger: the diverse nature of damage-associated molecular patterns. J Biol Chem 289: 35237-35245.

Schaefer L, Babelova A, Kiss E, Hausser H-J, Baliova M, Krzyzankova M, Marsche G, Young MF, Mihalik D, Götte M, Malle E, Schaefer RM, Gröne H-J (2005) The matrix component biglycan is proinflammatory and signals through Toll-like 
receptors 4 and 2 in macrophages. J Clin Invest 115: 2223-2233.

Schmid B, Hausmann O, Hitzl W, Achermann Y, Wuertz-Kozak K (2020) The role of Cutibacterium acnes in intervertebral disc inflammation. Biomedicines 8: 186. DOI: 10.3390/biomedicines 8070186 .

Seny D de, Cobraiville G, Charlier E, Neuville S, Esser N, Malaise D, Malaise O, Calvo FQ, Relic B, Malaise MG (2013) Acute-phase serum amyloid A in osteoarthritis: regulatory mechanism and proinflammatory properties. Plos One 8: e66769. DOI: 10.1371/journal.pone.0066769.

Shah BS, Burt KG, Jacobsen T, Fernandes TD, Alipui DO, Weber KT, Levine M, Chavan SS, Yang H, Tracey KJ, Chahine NO (2018) High mobility group box-1 induces pro-inflammatory signaling in human nucleus pulposus cells via Toll-like receptor 4-dependent pathway. J Orthop Res 37: 220-231.

Shang P, Tang Q, Hu Z, Huang S, Hu Y, Zhu J, Liu H (2020) Procyanidin B3 alleviates intervertebral disc degeneration via interaction with the TLR4/MD-2 complex. J Cell Mol Med 24: 3701-3711.

Shyu K-G, Wang B-W, Lin C-M, Chang H (2010) Cyclic stretch enhances the expression of Toll-like receptor 4 gene in cultured cardiomyocytes via p38 MAP kinase and NF- $\kappa$ B pathway. J Biomed Sci 17: 15. DOI: 10.1186/1423-0127-17-15.

Singh K, Masuda K, Thonar EJ-MA, An HS, Cs-Szabo G (2009) Age-related changes in the extracellular matrix of nucleus pulposus and anulus fibrosus of human intervertebral disc. Spine 34: 10-16.

Stirling A, Worthington T, Rafiq M, Lambert PA, Elliott TS (2001) Association between sciatica and Propionibacterium acnes. Lancet 357: 2024-2025.

Studer RK, Aboka AM, Gilbertson LG, Georgescu H, Sowa G, Vo N, Kang JD (2007) p38 MAPK inhibition in nucleus pulposus cells. Spine 32: 2827-2833.

Sztrolovics R, Alini M, Roughley PJ, Mort JS (1997) Aggrecan degradation in human intervertebral disc and articular cartilage. Biochem J 326: 235-241.

Sztrolovics R, Grover J, Cs-Szabo G, Shi S, Zhang Y, Mort JS, Roughley PJ (2002) The characterization of versican and its message in human articular cartilage and intervertebral disc. J Orthop Res 20: 257-266.

Takashima K, Matsunaga N, Yoshimatsu M, Hazeki K, Kaisho T, Uekata M, Hazeki O, Akira S, Iizawa Y, Ii M (2009) Analysis of binding site for the novel small-molecule TLR4 signal transduction inhibitor TAK-242 and its therapeutic effect on mouse sepsis model. Brit J Pharmacol 157: 1250-1262.

Takeda K, Akira S (2015) Toll-like receptors. Curr Protoc Immunol 109: 14.12.1-14.12.10. DOI: 10.1002/0471142735.im1412s109.

Tang G, Wang Z, Chen J, Zhang Z, Qian H, Chen Y (2018) Latent infection of low-virulence anaerobic bacteria in degenerated lumbar intervertebral discs. BMC Musculoskelet Disord 19: 445. DOI: 10.1186/ s12891-018-2373-3.

Tanga FY, Nutile-McMenemy N, DeLeo JA (2005) The CNS role of Toll-like receptor 4 in innate neuroimmunity and painful neuropathy. Proc Natl Acad Sci U S A 102: 5856-5861.

Tian Y, Yuan W, Fujita N, Wang J, Wang H, Shapiro IM, Risbud MV (2013) Inflammatory cytokines associated with degenerative disc disease control aggrecanase-1 (ADAMTS-4) expression in nucleus pulposus cells through MAPK and NF- $\kappa$ B. Am J Pathology 182: 2310-2321.

Vos T, Flaxman AD, Naghavi M, Lozano R, Michaud C, Ezzati M, Shibuya K, Salomon JA, Abdalla S, Aboyans V, Abraham J, Ackerman I, Aggarwal R, Ahn SY, Ali MK, AlMazroa MA, Alvarado M, Anderson HR, Anderson LM, Andrews KG, Atkinson C, Baddour LM, Bahalim AN, Barker-Collo S, Barrero LH, Bartels DH, Basáñez M-G, Baxter A, Bell ML, Benjamin EJ, Bennett D, Bernabé E, Bhalla K, Bhandari B, Bikbov B, Abdulhak AB, Birbeck G, Black JA, Blencowe H, Blore JD, Blyth F, Bolliger I, Bonaventure A, Boufous S, Bourne R, Boussinesq M, Braithwaite T, Brayne C, Bridgett L, Brooker S, Brooks P, Brugha TS, Bryan-Hancock C, Bucello C, Buchbinder R, Buckle G, Budke CM, Burch M, Burney P, Burstein R, Calabria B, Campbell B, Canter CE, Carabin H, Carapetis J, Carmona L, Cella C, Charlson F, Chen H, Cheng AT-A, Chou D, Chugh SS, Coffeng LE, Colan $\mathrm{SD}$, Colquhoun S, Colson KE, Condon J, Connor MD, Cooper LT, Corriere M, Cortinovis M, Vaccaro KC de, Couser W, Cowie BC, Criqui MH, Cross M, Dabhadkar KC, Dahiya M, Dahodwala N, DamsereDerry J, Danaei G, Davis A, Leo DD, Degenhardt L, Dellavalle R, Delossantos A, Denenberg J, Derrett S, Jarlais DCD, Dharmaratne SD, Dherani M, DiazTorne C, Dolk H, Dorsey ER, Driscoll T, Duber H, Ebel B, Edmond K, Elbaz A, Ali SE, Erskine H, Erwin PJ, Espindola P, Ewoigbokhan SE, Farzadfar F, Feigin V, Felson DT, Ferrari A, Ferri CP, Fèvre EM, Finucane MM, Flaxman S, Flood L, Foreman K, Forouzanfar MH, Fowkes FGR, Franklin R, Fransen M, Freeman MK, Gabbe BJ, Gabriel SE, Gakidou E, Ganatra HA, Garcia B, Gaspari F, Gillum RF, Gmel G, Gosselin R, Grainger R, Groeger J, Guillemin F, Gunnell D, Gupta R, Haagsma J, Hagan H, Halasa YA, Hall W, Haring D, Haro JM, Harrison JE, Havmoeller R, Hay RJ, Higashi H, Hill C, Hoen B, Hoffman H, Hotez PJ, Hoy D, Huang JJ, Ibeanusi SE, Jacobsen KH, James SL, Jarvis D, Jasrasaria R, Jayaraman S, Johns N, Jonas JB, Karthikeyan G, Kassebaum N, Kawakami N, Keren A, Khoo J-P, King CH, Knowlton LM, Kobusingye O, Koranteng A, Krishnamurthi R, Lalloo R, Laslett LL, Lathlean T, Leasher JL, Lee YY, Leigh J, Lim SS, Limb E, Lin JK, Lipnick M, Lipshultz SE, Liu W, Loane M, Ohno SL, Lyons R, Ma J, Mabweijano J, MacIntyre MF, Malekzadeh R, Mallinger L, Manivannan S, Marcenes W, March L, Margolis DJ, Marks GB, Marks R, Matsumori A, Matzopoulos R, Mayosi BM, McAnulty JH, McDermott MM, McGill N, McGrath J, Medina-Mora ME, Meltzer M, Memish ZA, Mensah GA, Merriman TR, Meyer A-C, Miglioli V, Miller M, Miller TR, Mitchell PB, Mocumbi AO, Moffitt TE, Mokdad AA, Monasta L, Montico M, Moradi-Lakeh 
M, Moran A, Morawska L, Mori R, Murdoch ME, Mwaniki MK, Naidoo K, Nair MN, Naldi L, Narayan KV, Nelson PK, Nelson RG, Nevitt MC, Newton CR, Nolte S, Norman P, Norman R, O'Donnell M, O'Hanlon S, Olives C, Omer SB, Ortblad K, Osborne R, Ozgediz D, Page A, Pahari B, Pandian JD, Rivero AP, Patten SB, Pearce N, Padilla RP, Perez-Ruiz F, Perico N, Pesudovs K, Phillips D, Phillips MR, Pierce K, Pion S, Polanczyk GV, Polinder S, Pope CA, Popova S, Porrini E, Pourmalek F, Prince M, Pullan RL, Ramaiahk D, Ranganathan D, Razavi H, Regan M, Rehm JT, Rein DB, Remuzzi G, Richardson K, Rivara FP, Roberts T, Robinson C, Leòn FRD, Ronfani L, Room R, Rosenfeld LC, Rushton L, Sacco RL, Saha S, Sampson U, Sanchez-Riera L, Sanman E, Schwebel DC, Scott JG, Segui-Gomez M, Shahraz S, Shepard DS, Shin H, Shivakoti R, Silberberg D, Singh D, Singh GM, Singh JA, Singleton J, Sleet DA, Sliwa K, Smith E, Smith JL, Stapelberg NJ, Steer A, Steiner T, Stolk WA, Stovner LJ, Sudfeld C, Syed S, Tamburlini G, Tavakkoli M, Taylor HR, Taylor JA, Taylor WJ, Thomas B, Thomson WM, Thurston GD, Tleyjeh IM, Tonelli M, Towbin JA, Truelsen T, Tsilimbaris MK, Ubeda C, Undurraga EA, Werf MJ van der, Os J van, Vavilala MS, Venketasubramanian N, Wang M, Wang W, Watt K, Weatherall DJ, Weinstock MA, Weintraub R, Weisskopf MG, Weissman MM, White RA, Whiteford H, Wiersma ST, Wilkinson JD, Williams HC, Williams SR, Witt E, Wolfe F, Woolf AD, Wulf S, Yeh P-H, Zaidi AK, Zheng Z-J, Zonies D, Lopez AD, Murray CJ (2013) Years lived with disability (YLDs) for 1160 sequelae of 289 diseases and injuries 19902010: a systematic analysis for the Global Burden of Disease Study 2010. Lancet 380: 2163-2196.

Wang P, Zhu F, Tong Z, Konstantopoulos K (2011) Response of chondrocytes to shear stress: antagonistic effects of the binding partners Toll-like receptor 4 and caveolin-1. FASEB J 25: 3401-3415.

Wang Q, Pan X, Wong HH, Wagner CA, Lahey LJ, Robinson WH, Sokolove J (2014) Oral and topical boswellic acid attenuates mouse osteoarthritis. Osteoarthritis Cartilage 22: 128-132.

Wolfson RK, Mapes B, Garcia JGN (2014) Excessive mechanical stress increases HMGB1 expression in human lung microvascular endothelial cells via STAT3. Microvasc Res 92: 50-55.

Wuertz K, Vo N, Kletsas D, Boos N (2012) Inflammatory and catabolic signalling in intervertebral discs: The roles of NF- $\kappa$ B and MAP kinases. Eur Cell Mater 23: 102-120.

Yang J, Jiang H, Yang J, Ding J-W, Chen L-H, Li S, Zhang X-D (2009) Valsartan preconditioning protects against myocardial ischemia-reperfusion injury through TLR4/NF- $\kappa$ B signaling pathway. Mol Cell Biochem 330: 39-46.
Youn HS, Saitoh SI, Miyake K, Hwang DH (2006) Inhibition of homodimerization of Toll-like receptor 4 by curcumin. Biochem Pharmacol 72: 62-69.

Yuan Y, Zhou Z, Jiao Y, Li C, Zheng Y, Lin Y, Xiao J, Chen Z, Cao P (2017) Histological identification of Propionibacterium acnes in nonpyogenic degenerated intervertebral discs. Biomed Res Int 2017: 1-7.

Zhang Q, Weng Y, Jiang Y, Zhao S, Zhou D, Xu N (2018) Overexpression of miR-140-5p inhibits lipopolysaccharide-induced human intervertebral disc inflammation and degeneration by downregulating Toll-like receptor 4 . Oncol Rep 40: 793-802.

Zhao Y, Xin Y, Gao J, Teng R-Y, Chu H-C (2015) Analgesic effect of TAK-242 on neuropathic pain in rats. Int J Clin Exp Med 8: 11202-11207.

Zwambag DP, Molladavoodi S, Guerreiro MJ, DeWitte-Orr SJ, Gregory DE (2020) Immunostimulatory capacity of decorin in the rat tail intervertebral disc and the mechanical consequence of resultant inflammation. Eur Spine J 29: 1641-1648.

\section{Discussion with Reviewer}

Zhen Li: Do you think blocking of TLRs could be used in the future as a treatment therapy for IVD disease? Authors: We believe so. Since the TLRs are an integral part of the cytokine-mediated inflammatory process seen at the core of IVD degeneration and that alarmins are increasingly found in degenerating discs, the literature supports the fact that inhibiting this pathway leads to a dampening of the catabolism and inflammation found in IVDs. However, it remains to be seen whether this dampening is enough to bring balance to tissue homeostasis to arrest the vicious cycle of degeneration.

Zhen Li: Blocking TLRs seems to offer a promising therapeutic treatment for management of inflammatory and degenerative disc disease. Is there any side effect anticipated if TLR blockers are applied systematically or locally for treatment of disc disease? Authors: TLRs are important as the first line of defence at the core of innate immunity. Therefore, a systemic inhibitory approach could bring adverse immunosuppressive effects. Ideally, treatements should be applied locally with slow release or shortterm exposure at a higher dose.

Editor's note: The Guest Editor responsible for this paper was Andrea Vernengo. 